\title{
The Development of China's Service Trade in Recent Years
}

\author{
Chunling Pan", Jie Lv \\ The College of Economics and Management, Shenyang Agricultural University, Shenyang, China. \\ Email: "panchunling91@163.com, jieluesy@163.com
}

Received March 14 ${ }^{\text {th }}, 2013$; revised April 20 ${ }^{\text {th }}, 2013$; accepted April 28 ${ }^{\text {th }}, 2013$

Copyright (c) 2013 Chunling Pan, Jie Lv. This is an open access article distributed under the Creative Commons Attribution License, which permits unrestricted use, distribution, and reproduction in any medium, provided the original work is properly cited.

\begin{abstract}
Services trade is an important component of international trade. Its importance is drawing growing academic and government attention. This paper analyzes the current development of China's service trade. For the transport and tourism are two of the more important services sector, this paper gives more detailed attention. Meanwhile, this paper analyzes the some problems faced by the development of China's service trade.
\end{abstract}

Keywords: China; Services Trade; Development; Problems

\section{Introduction}

Since the 1980s, with the development of trade in goods, China's service trade volume has been expanded. As can be seen from Figure 1, since 2000, China's service trade has developed rapidly, China's service export share in world services exports rose from $2.0 \%$ in 2000 to $4.2 \%$ in 2009; services imports of the world imports of services rose from $2.4 \%$ in 2000 to $5.1 \%$ in 2007; of the world's services import and export value rose from $2.2 \%$ in 2000 to $4.7 \%$ in 2009 .

Tourism, transport and other business services and other resources, labor-intensive traditional trade in services has been China's main export sectors of trade in services, except for a few years, the sum of the three major traditional exports of services accounted for the proportion of total services exports are in the $80 \%$ or more. The tourism industry has been China's service trade exports accounted for the largest sector, especially in 2000-2009, the proportion of their exports are more than $50 \%$, the proportion has decreased since 2003, exports of tourism services in 2009 is one of the lowest years, only $30.6 \%$, but exports continued to hold the first; other business services by 2005, its exports have been the second highest proportion, relegated to third in 2006 Bit; the proportion of the transport sector increased year by year since 2000, after 2006, more than other business services and in second place. On the contrary, on behalf of knowledge, technology and capital-intensive service

\footnotetext{
"Corresponding author.
}

sectors of the emerging small share of exports. Consulting services since 2001, relatively rapid development of computer and information services over the same period of slow growth, in addition, finance, insurance, telecommunications, royalties and license fees to, audiovisual industry trend is not obvious, only served five. Trade in services within 3\% of total exports.

\section{The Development of China's Transportation Service Trade}

As a capital-intensive trade in services, transport services, trade in services trade in China occupies an important position. Over the years, trade in transport services into and exports not only retaining its position as China's service trade import and export of the top three, and is one of the largest of China's service trade deficit.

Shown in Figure 2, since 2000, both from the export or import growth rate terms, China's transportation services are maintained rapid trade growth, trade in services each year into the transport and export are maintained above 20\% the growth rate. Can also be seen from Figure 2, the transport services exports growth rate should be slightly higher than import growth, which shows that since 2000, China's transport services has improved the international competitiveness of China's transport services, transport services and foreign gap continued to narrow. As transport services are capital-intensive Industries, therefore, China's transportation service trade export growth rate faster than the growth rate of imports 


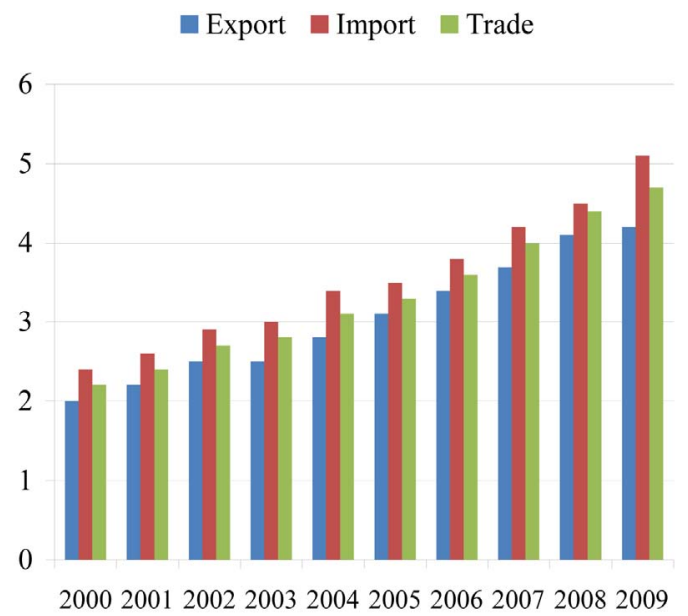

Figure 1. The share of China's service export, import and trade in global total service trade between 2000 and 2009 (\%).

\section{Export $\quad$ Import}

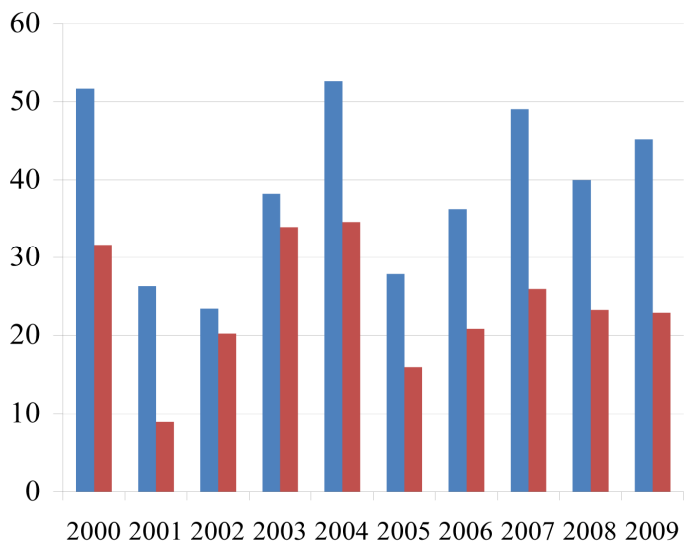

Figure 2. The growth rate of China's transportation service trade between 2000 and 2009 (\%).

can indicate the fact that in recent years in the service sector, compared with other factors of production, the share capital increase the proportion of China's service sector and improve their ability to use capital, China's service industry gradually from the resources, labor-intensive industries to capital-intensive industries.

Transportation services exports out of China's service trade accounts for the proportion of El rising $15.06 \%$ in 2000 rose to $27.89 \%$ in 2009 , transport services, travel services has become second only to China's second largest services export industry; although transportation services trade is the largest of China's service trade import items, but over the past 10 years, imports of transport services trade accounts for China's service trade little change in proportion of imports, has been stable at around 33\%. Import and export of transport services through the trade account for the proportion of China's service trade import and export comparison can be fur- ther found that China's service trade is from the traditional resource-intensive to capital-intensive, industrial structure, China's service trade, the gradual rise from junior to senior, industrial structure upgrade to accelerate the pace constantly.

\section{The Development of China's Tourism Service Trade}

As a resource-intensive service industry [1], tourism has been China's service trade in traditional industries, but also over the years, China's largest export trade in services industries. The quality of tourism services, trade development, in a way directly related to the overall development of China's service trade situation.

Since 2000, China's tourism services exports growth and import growth rate has maintained a rising trend, but in 10 years, five years lower than the import growth rate of export growth, export growth and import the rest of the year the growth rate difference same, 10 years, only 2004 higher export growth than import growth rate nearly 22 percentage points in 2003, negative growth in exports was mainly "atypical pneumonia" in 2004, following the surge in exports is only to restore growth, export growth in 2005 has returned to normal. This shows that, since 2000, with the continuous improvement of living standards, demand for foreign products, increasing tourism, which appeared in the import trade in tourism services export growth rate faster than the case. Compared with trade in transport services, whether export or import growth rate, tourism, transportation services, trade in services trade are lower than the maximum rate of increase is lower than the transport trade. This shows that, 10 years, China's tourism trade in services, although a rapid growth, but compared to other forms of trade in services is limited growth, which also illustrates one aspect of the present conditions, relying solely on resources to the development of China's traditional advantage of the service sector has been very difficult to support China's traditional advantage of the sustainable development of trade in services. Therefore, the traditional advantages of the service sector to tap the potential of this industry, give full play to their comparative advantage, to participate in international competition in services, has become a priority in China's traditional strengths services industry, especially in front travel service industry is an important issue.

Trade in tourism services exports accounted for the proportion of China's service trade exports increased and then showed a downward trend, from 2000 to 2001 growth in 2001 reached the highest level of $54.07 \%$ in 2002 , began to decline in 2009 , dropped to $30.66 \%$; another, although the proportion has declined in recent years, but remained above 30\%, indicating that China's service trade exports high dependence on tourism. China 
trade in tourism services imports in the same proportion of trade in services imports increased and then decreased showing a trend of development has been relegated to the second largest service trade of China's imports of the project.

\section{The Development of China's Other Service Trade}

In the WTO on trade in services statistics, other commercial services trade is defined in the transport trade in services, tourism services outside of the trade in services trade, with China's international balance of payments (BOP tables) contrast can be found, WTO statistics in other commercial services trade, including the BOP tables communication services, construction services, insurance services, financial services, computer and information services, royalties and license fees, consulting services, advertising services, audiovisual services, and BOP not mentioned in the table other business services 10. In addition to the BOP table which is not mentioned in other commercial services, others are knowledge, technology-intensive new services. In recent years, rapid growth in the emerging trade in services, the proportion of total world trade in services is increasing; the world economy is playing an increasingly important role, but also the future direction of development of trade in services.

Since 2000, China has various other business services trade faster growth, but growth is very unstable. To communication services, for example, export growth rate in 2000 , and $128.28 \%$ in 2001 , dropped to a $79.85 \%$, showing a great deal of volatility. Not only communication services, construction services, insurance services, financial services, computer and information services, royalties and license fees, consulting services, advertising and promotion services, film and audio-visual services, and BOP in the first place not mentioned in the commercial services of export growth are ups and downs. Our knowledge, the emerging technology-intensive services exports has two outstanding features: first, growing faster, and showing a good momentum of development; second, although faster growth rate, but compared with the very traditional service stable, highly vulnerable to domestic and international situation and other relevant factors, greater uncertainty.

And export growth rates similar to the import growth rate also showed high but volatile growth characteristics. The main reason is: First, as China's rapid economic development, China's foreign knowledge and technology-intensive services and products, especially financial services, insurance services, computer and information services, advertising and promotional services, and production are closely related to production services, rapid growth in demand, and our service is the supply of such services is limited, resulting in the production of our new services faster import growth. Second, exports and emerging service industries similar to the import of China's emerging service industries also vulnerable to the impact of international and domestic factors, so that the import of new service industries volatile.

Trade from the other services account for a large proportion of China's service trade export point of view, since 2000, in addition to the table in front at the BOP and other business services not mentioned projects, rest of the other commercial services exports accounted for our Although the proportion of trade in services exports showing a rising trend, but the proportion of less than $10 \%$. Of particular note is that in recent years, consulting services exports accounted for the proportion of China's service trade exports increased from $2.31 \%$ in 2000 to $11.09 \%$ in 2009 , has become the travel services, transport services and BOP at the table before other business services not mentioned after the service trade of China's fourth largest export industry. This shows that in recent years. Country's international competitiveness consulting services increasing, the gap with the foreign industry is gradually narrowing. However, compared to better reflect the knowledge, technical content, such as insurance services, financial services, royalties and license fees, film and audio-visual services, service industries accounted for the proportion of China's service trade exports did not exceed 1\%. Therefore, compared with the traditional services, new services in China's service trade in the share of exports is still small, China's service trade exports are still based on resource-intensive and capitalintensive traditional, extensive way trade in services exports, compared with developed countries there is still a big gap.

And various other service trade exports accounted for the proportion of China's service trade exports is similar, except at the BOP table is not mentioned in his previous business services, accounting for the rest of the other services imports into China's service trade is relatively small share of El, also are less than $10 \%$, of which communication services, financial services, advertising and promotional services as well as film and audio-visual services each accounted for the proportion of China's service trade import were below 1\%. But this does not explain our products to foreign demand for these services less, here is a major cause of these services because of China's trade has not been fully liberalized, so that these services accounted for China's service trade import into a smaller proportion.

\section{Main Factors Restricting the Development of China's Service Trade}

Since reform and opening, China's rapid development of service industry, service trade import and export volume 
increased, but, in general, the openness of China's service trade is not high, the field is not wide. This is because China has long regarded as the service industry, manufacturing of accessories, do not pay attention to the development of producer services. Although the introduction of a multinational manufacturing sector, services for multinational corporations but often productive service sectors excluded. China's service industry should be open later than overall manufacturing sector, the degree of openness is far lower than in manufacturing.

At present, China's openness to foreign investment service industry is about $7 \%$ more than when we join the WTO commitments, but much lower than in Western countries in recent years, trade in services $10 \%$ openness. As early as in 1999, openness of the United Kingdom, Korea, Italy, France, reached 12.0\%, 11.9\%, 11.3\% and $10.6 \%$. At present, China still has many industries; especially the low degree of openness of modern service industry such as telecommunications, civil aviation and railway sector is still in a monopoly being. As the monopoly, resulting in poor quality of service, market competitiveness is low, not only damages the interests of consumers, but also hindered the development of this industry. In fact, China's service trade to enhance the openness of trade in services depends on a large development; the key is to absorb foreign advanced technology, experience, development of trade in high valueadded services to improve the value of China's service trade.

At present, China's trade in services management and coordination agency is suitable for the Ministry of Commerce. Trade in services is mainly responsible for strategy and policy formulation, international multilateral negotiations, service utilization of foreign investment policy matters. This service management system requirements and GAPS there is a gap, mainly as follows: lack of a unified trade in services coordination and management departments, central. On trade in services of local policies and regulations are not uniform; current management of trade in services is still fragmented state, the relevant functional departments of bull management, cross-management, fragmentation is serious; net addition, the definition of China's service sector, Statistics scope and criteria for the classification. With developed market economies, and inconsistent with international practice, all of which impede trade in services are the main factors.

Although the current international trade in services showed the general trend of liberalization and globalization, but to protect certain domestic industries vulnerable services, countries with weak international competitiveness of the domestic service market opening tend to impose many restrictions [2]. In the future between the developed and emerging countries in the field of service trade liberalization will aggravate the opposition, the hidden barriers to services trade. Cover will continue to reflect the trend. As a developing country, China's trade in services, the main advantage in tourism, construction, transport and other labor-intensive service sectors. These services are required, the low-skilled labor as intermediate inputs, requires the movement of persons. But the developed countries the issue of cross-border movement restrictions are more natural persons to provide their services for the commitment in principle, but only with the establishment of commercial organizations providing services linked to a small number of senior management or technical staff mobility provisions of an exceptional commitment to the table, which makes natural persons providing services to a large extent only as "commercial presence" of the supplement, the cross-border flow is also highly dependent on the establishment of foreign business organizations in need. In addition, some, such as immigration restrictions, certification, technical standards, foreign exchange restrictions and other barriers to services trade has become a substantial export of China's service trade barriers.

Today's world, service is the labor-intensive to technology-intensive [3], emerging trade in services relative share in total trade expanded. Modern service industry knowledge, technology-intensive industries, requires a large number of professional solid, high-quality technical and management personnel. However, the comparative advantage of China's service industry is labor-intensive services. Service providers only have a general culture of quality can be after or after a simple training posts; coupled with China's service is not enough emphasis on the training of professionals, led to the current quality of service sector employees are generally not high. This kind of situation cannot meet the supply needs of the modern service industry development, undermined China's international competitiveness in trade in services.

\section{Conclusions and Discussions}

The overall level of development of China's service trade is not high, especially in the structure left behind. Commodity structure of trade in services from the point of view, exports are concentrated in tourism, transportation, etc. can take advantage of our relatively abundant natural and labor resources of the traditional service projects, in 2009 only two travel services and transportation services accounted for China's service trade exports of $57.36 \%$ and $58.72 \%$ of imports, although both compared with 2008 share of exports or imports have decreased, but still accounted for China's service trade exports and imports in half. In contrast, in the capital, technology, management experience, a high dependence on services, such as computer and information services, financial services, consulting services, patent services, advertising and pro- 
motional services, new services, import and export accounted for China's service import and export trade, especially exports, the proportion is still small. This shows that China's service trade development in a serious imbalance. While this structure in the short term China's economic growth and employment problems are more favorable, but in the long run, China's service industry and service trade development is rather negative.

In the new service, the Chinese share of imports is higher than the proportion of exports. This shows with the upgrading of China's industrial structure continues to accelerate the pace of China's emerging services for foreign products, particularly in the production of services, increasing demand for products, it also shows the development level of China's service industry and commodity structure of trade in services is still relatively behind the urgent need to improve our service capability of technological innovation, speed up industrial upgrading of China's service industry pace.

Finally, particular note is the emerging service sector cannot support the protection of the name of the real. China should encourage high-tech service industry to actively participate in international competition in the international market for development, rather than inwardlooking, blindly seeking government protection, as will always lag behind the developed countries, China's service industry structure and export structure of trade in services the upgrade does not arise.

\section{REFERENCES}

[1] J. Kaboski, "Education, Sectoral Composition and Growth," Review of Economic Dynamics, Vol. 12, No. 1, 2009, pp. 168-182. doi:10.1016/j.red.2008.07.003

[2] D. Acemoglu and V. Guerrieri, "Capital Deepening and Non-Balanced Economic Growth,” Journal of Political Economy, Vol. 116, No. 3, 2008, pp. 467-498. doi:10.1086/589523

[3] Z. Griliches, "Output Measurement in the Service Sectors,” National Bureau of Economic Research, Studies in Income and Wealth, Volume 56, University of Chicago Press, Chicago and London, 1992. doi:10.7208/chicago/9780226308890.001.0001 